\title{
The Homothorax homeoprotein activates the nuclear localization of another homeoprotein, Extradenticle, and suppresses eye development in D rosophila
}

\author{
Chi-Yun Pai, ${ }^{1}$ Tung-Sheng Kuo, ${ }^{2}$ Thomas J. Jaw, ${ }^{3}$ Estee Kurant, ${ }^{4}$ Cheng-Tse Chen, ${ }^{3}$ \\ Dmitri A. Bessarab, ${ }^{1}$ Adi Salzberg ${ }^{4}$ and Y. Henry Sun ${ }^{1,3,5}$ \\ ${ }^{1}$ Institute of M olecular Biology, Academia Sinica, N ankang, Taipei 11529, Taiwan, Republic of China, ${ }^{2}$ Institute of Life \\ Science, N ational Sun Yat-Sen University, Kaohsiung, Taiwan; ${ }^{3}$ Institute of Genetics, N ational Yang-M ing University, \\ Shipai, Taipei, Taiwan, ${ }^{4} U$ nit of Genetics, Rappaport Faculty of M edicine, Technion-Israel Institute of Technology, \\ Haifa 31096, Israel
}

The Extradenticle (Exd) protein in D rosophila acts as a cofactor to homeotic proteins. Its nuclear localization is regulated. We report the cloning of the D rosophila homothorax (hth) gene, a homolog of the mouse Meis1 proto-oncogene that has a homeobox related to that of exd. Comparison with Meisl finds two regions of high homology: a novel MH domain and the homeodomain. In imaginal discs, hth expression coincides with nuclear Exd. hth and exd also have virtually identical, mutant clonal phenotypes in adults. These results suggest that hth and exd function in the same pathway. We show that hth acts upstream of exd and is required and sufficient for Exd protein nuclear localization. We also show that hth and exd are both negative regulators of eye development; their mutant clones caused ectopic eye formation. Targeted expression of hth, but not of exd, in the eye disc abolished eye development completely. We suggest that hth acts with exd to delimit the eye field and prevent inappropriate eye development.

[Key Words: homothorax; extradenticle; homeodomain protein; nuclear localization; eye; Drosophila]

Received October 16, 1997; revised version accepted December 2, 1997.

Homeotic genes determine the identity of body segments in the anterior-posterior axis in Drosophila. These genes contain a DNA-binding domain, the homeodomain (HD), and act as transcriptional regulators. It was expected that different HD proteins bind to a different set of DNA targets to exert their functional specificity. However, in vitro binding studies revealed that most Homeobox (HOX) proteins bind very similar sequences with similar affinities (for review, see M ann 1995). Thus, it was proposed that the HOX proteins require the cooperation of cofactor proteins to enhance their DN A-binding specificity. The extradenticle (exd) gene and its mammalian homologs, the Pbx genes, were found to encode HD proteins that can act as cofactors to many HOX proteins.

Mutations in exd do not affect the expression of the homeotic genes U Itrabithorax ( $\mathrm{U}$ bx) and A netennapedia (Antp) but caused homeotic transformation of the embryonic segments (Peifer and Wieschaus 1990). exd al so

${ }^{5}$ Corresponding author.

E-MAIL mbyhsun@ccvax.sinica.edu.tw; FAX (886-2) 2782-6085. encodes a HD protein (Rauskol b et al . 1993). The suggestion that Exd forms a heterodimer with the HOX proteins and alters their DNA-binding specificity has been confirmed by in vitro and in vivo studies (for review, see Mann 1995). Similar results were shown for PBX (for review, see Lu et al. 1995; Mann 1995; Phelan et al. 1995). The HOX monomer and the HOX-Exd heterodimer can have different sequence specificity, and Exd binding to different HOX proteins selects different binding sites (Chan and Mann 1996; Chang et al. 1996). It was also proposed that the Exd-HOX interaction has a more general role in turning $\mathrm{HOX}$ proteins from repressors to activators (Pinsonneault et al. 1997).

Exd is not uniformly available to interact with the HOX proteins. Thus, the availability of Exd provides one way to modulate the HOX activity. Regulation of Exd can be achieved at three levels. The first is on transcription. Although exd maternal transcript and early zygotic transcript are uniformly distributed in early embryo, zygotic expression of exd is not uniform in late embryo (e.g., expression in the epidermis and CNS is higher in the thoracic segments than in the abdominal segments) (Flegel et al. 1993; Rauskolb et al. 1993). This expression 
pattern is regulated by HOX genes in the Bithorax complex (Rauskolb et al. 1993), probably at the transcription level. The second is probably at the translation level or affects protein stability. The exd mRNA is uniform in imagi nal discs (Rauskol b et al. 1995), but Exd protein has a patterned distribution in the discs (Gonzalez-Crespo and Morata 1995, 1996). The third level is at the subcelIular localization of Exd. Exd is not located in the nucleus in all cells. The distribution of nuclear Exd (Aspland and White 1997) correl ates with the functional requirement for exd, indicating that only the nuclear Exd can exert its function. In the embryonic midgut, Exd nuclear localization in the endoderm is regulated by $D e-$ capentapl egic (Dpp) and Wingless (Wg) signaling (M ann and Abu-Shaar 1996). However, Dpp and Wg are not the only signals regulating Exd nuclear localization (Mann and Abu-Shaar 1996; Aspland and White 1997).

exd has other roles in addition to its homeotic cofactor function. exd mutant clones caused ectopic eye formation in the ventral head, ventral to dorsal transformation in the imaginal abdomen, affected bristle patterning in the thorax and wing, and affected the proximal leg development (Gonzalez-Crespo and Morata 1995; Rauskolb et al. 1995), all of which are not associated with the anterior-posterior segmentation function of the HOX genes. In vitro studies showed that Exd alone can bind to specific DNA sequences (Lu and Kamps 1996), suggesting that it can act as a transcription factor by itself in vivo.

We report the cloning and characterization of the homothorax (hth) gene in Drosophila. hth was found to act as a homeotic cofactor in embryonic devel opment, similar to exd (Rieckhof et al. 1997). We found the gene to be a homolog of the mouse Meisl (myeloid ecotropic viral iintegration site 1) proto-oncogene, which has a homeobox related to that of exd (M oskow et al. 1995). It is expressed in specific patterns in the embryo and imaginal discs. In this report, we focus on the role of hth in imaginal development. Its expression pattern in the imaginal discs and mutant clonal phenotypes in adults were virtually identical to those of exd, suggesting that hth and exd function in the same pathway. We show that $\mathrm{H}$ th activates the nuclear localization of Exd. This is the first case of a HD protein regulating the subcellular localization of another HD protein. In addition, we present evidence that hth and exd act in the same pathway as a negative regulator of eye development. Their normal function in adult head development may be to delimit the eye field and to prevent inappropriate eye formation.

\section{Results}

Cloning of the hth gene

Two P[lacW] enhancer trap lines (P1 and P2) have been isolated on the basis of an interesting expression pattern of their $w^{+m}$ reporter gene, which was suppressed in the anterior two thirds of the developing eye and showed a posteriorly pigmented eye phenotype (Sun et al. 1995). The P[lacW ] in the two lines have been mapped to 86C 1-
4. P2 is homozygous lethal because of the P[lacW] insertion. The P1 homozygote has no apparent morphological defect, but imprecise excision of $\mathrm{P}[\mathrm{lacW}]$ from $\mathrm{P} 1$ can result in lethal mutations that are allelic to $\mathrm{P} 2$, and al so allelic to hth and dorsotonal (dtl) mutations (Jürgens et al. 1984; Salzberg et al. 1994, 1997). Thus, these mutations define the hth locus. A nother lethal locus, toothless (tss), has been mapped to the same region and al so have P-tagged mutants with the posterior eye pigmentation phenotype (Pradip Sinha, pers. comm.) Complementation tests showed that tss and hth are different loci (data not shown). Mutant hth and tss embryos have similar head defects. Two tss mutants (tss ${ }^{47}$ and tss $^{470}$ ) were also defective for $h$ th. These results suggested that the two genes are very closely located or overlapping, and may be under similar regulation and have similar developmental functions.

Genomic fragments flanking the $P[\mathrm{lacW}]$ insert site in $\mathrm{P} 1$ were isol ated and used as probes to screen an imaginal disc CDNA library. Two nonoverlapping groups of cDNAs were identified, thus defining two transcription units (Fig. 1A). Group II consists of 8 independent overlapping clones (Fig. 1B). The CDN As hybridized to four separate genomic fragments (Fig. 1A), suggesting that the gene has at least four exons. The P[lacW] in the hth ${ }^{1422-4}$ and hth ${ }^{1323-7}$ mutants inserted 63 and 347 bp, respectively, upstream of the 5 ' end of the group II cDN A clone 7 (Fig. 1A). Therefore, we suspected that the group II transcription unit corresponds to the hth gene. To check this possibility, we tested whether the CDN A can rescue the lethality associated with hth loss-of-function mutations.

hs-hth transgenic strains were made using the 1.6-kb ORF from clone 7 fused to a hsp70 promoter. In wildtype background, a 2-hr heat shock induction of the hshth transgene in the embryonic stage caused significant lethality, the effect in the early stages [0-4, 4-8 hr AEL after egg laying] being the strongest. However, the few flies that survived to adulthood were morphologically normal. Induction of hth overexpression during the third instar larval and early pupal stages caused severe shortening of the legs. The shortening was attributable to the lack or shortening of the tibia and tarsal segments. In hth mutants, hs-hth induction resulted in the rescue to adulthood of $\sim 15 \%$ of the mutants. The rescued mutant flies have normal head, notum, and abdomen. Their legs were severely shortened, similar to the effect of hs-hth expression in wild type. Although only the weak hth allele can be rescued to adulthood, its rescue demonstrated unambiguously that the group II transcription unit corresponds to the hth gene.

Group I CDNA consists of a single clone (clone 1), located in the intronic region of the group II transcription unit. The cDNA has 3' poly(A) and an ORF starting from the $5^{\prime}$ end of the CDNA and without ATG, apparently missing the $5^{\prime}$ end. The ORF encodes 88 amino acids, and has no significant homology in the genome databases. P1-K1-8 is a lethal hth mutant derived from $\mathrm{P} 1$ by imprecise excision of $\mathrm{P}[\mathrm{lacW}]$. Southern blot and sequencing showed that the region hybridizing to the 


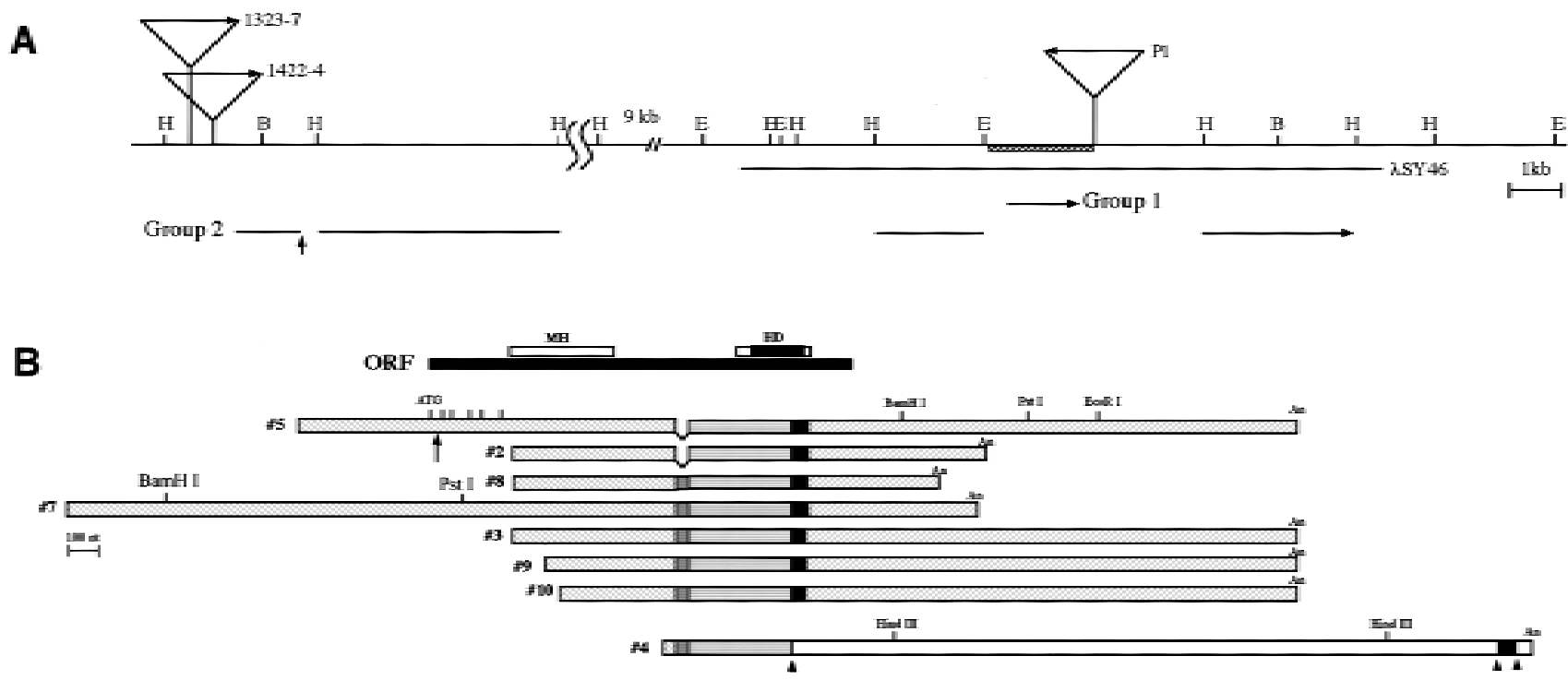

Figure 1. The hth locus and cDN As. (A) Map of the hth locus. The mapped hth genomic region and the clone $\lambda S Y 46$ is shown with horizontal lines. The region deleted in P1-K1-8 is shown as a hatched box. Sites of P[lacW] insertion are indicated. Restriction fragments hybridizing to the cDN A clones 7, 5, or 1 are shown bel ow as thick lines with arrows indicating the transcription direction.

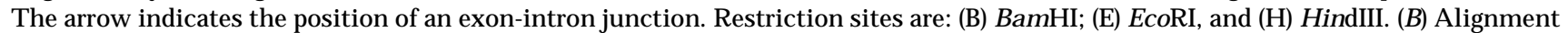
of the group II (hth) CDNA clones. The different regions are marked differently to indicate their relationship. The extra 45 bp is indicated as a dark gray box in clones 8, 7, 3, 9, 10, and 4. Six vertical bars on top of clone 5 indicate the positions of the first six in-frame ATGs. (An) Poly(A) stretches. The ORF and the two regions (the $\mathrm{MH}$ and HD domains), which are highly homologous to M eisl, are indicated. The arrow indicates the position of an exon-intron junction (same as in A). Arrowheads indicate potential splice junctions.

group I CDN A has been deleted (Fig. 1A). Complementation tests showed that P1-K1-8 is defective for hth, but not for tss. Therefore, group I cDN A is unlikely to correspond to the tss gene. It is possible that there is a smal I hth exon located in the region deleted in P1-K1-8. Alternatively, the deleted intron may be important for the regulation of hth expression.

\section{$\mathrm{Hth}$ is a homolog of the mouse Meis1 HD protein}

The hth CDNA clones reveal an ORF encoding a polypeptide of 487 amino acids (Fig. 2A). It is highly homologous to the mouse Meisla protein (M oskow et al. 1995) in two large regions (Fig. 2B). The $\mathrm{C}^{\prime}$ homology region (88\% identity in 83 residues) includes a HD $(93 \%$ identity in 60 residues). The HD has three additional residues in helix 1, thus belonging to the TALE (three-amino-acid loop extension) HD superfamily (Burglin 1994). It is homologous to the HD encoded by a number of genes from diverse phylogenetic groups, including human, mouse, chicken, Xenopus, Caenorhabditis el egans, A rabidopsis, and yeast (Fig. $2 \mathrm{C}$ legend). These define a HD family (the Meis1 family) that is distinct from three other related TALE families: Knotted, PBX, and MaT $\alpha 2$ (Fig. 2C). The $\mathrm{N}^{\prime}$ homology region (87\% identity in 119 residues) defines the MH domain (for Meisl and Homothorax; Fig. 2D). The $\mathrm{MH}$ domain is found only in $\mathrm{Hth}$ and the mouse, human, and Xenopus M eisl homologs. A stretch of basic residues (KKN QKKR) at the amino terminus of the HD might serve as the nuclear localization signal (NLS) (Nigg 1997).

Tissue distribution of Hth in imaginal discs is similar to that of Exd

We have determined the expression pattern of hth by in situ hybridization and by anti-Hth immunofluorescence staining of imaginal discs. The distribution of hth RNA and protein in the wild-type imaginal discs have the same pattern and are also the same as the lac $Z$ expression pattern in the enhancer trap line hth ${ }^{1422-4}$. (Fig. 3). The other hth enhancer trap lines have lac $Z$ expression patterns that are subsets of the hth pattern (data not shown), suggesting that each is responding to a different subset of regulatory elements. In the wing disc, the expression is present in the regions corresponding to notum, wing hinge, and ventral pleura (Fig. $3 \mathrm{~B}, \mathrm{E}, \mathrm{H}$ ). In the leg discs, the expression is in the periphery region, corresponding to the proximal segments of the legs (Fig. $3 A, D, G)$. In the antennal disc, the expression is in all but the arista region (Fig. 3C,F,I). In the eye disc, the expression is strong in the anterior region surrounding the eye field, including the regions corresponding to ptilinum, ocellus, and head capsules, and weak in the posterior and lateral margins of the eye disc (Fig. 3C,F,I). Very weak expression is detected in the posterior region composed of mature photoreceptors. $\mathrm{Hth}$ is also expressed in all cells of the peripodial membrane in the eye disc (not 
Pai et al.
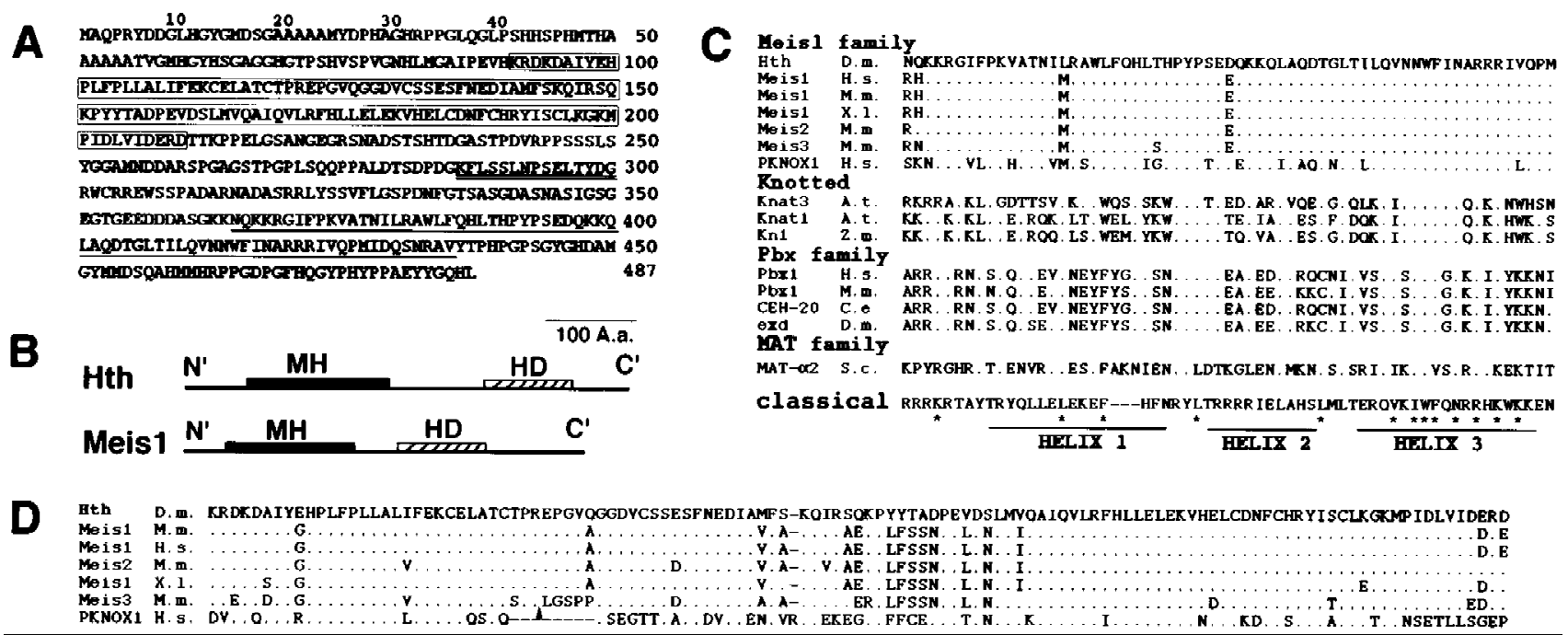

Figure 2. hth encodes a HD protein related to Meisl. (A) The peptide sequence of Hth translated from cDNA. The Meis1-Hth homology domain (MH domain) is boxed. The HD is underlined. The 15 residues present in some clones are double underlined. (B) The relative location of $\mathrm{MH}$ and $\mathrm{HD}$ in the M eisl and $\mathrm{H}$ th proteins. (C) Comparison of the HD domain of $\mathrm{H}$ th to that of the Miesl, Pbx, Knotted, and $\mathrm{M}$ aT $\alpha 2$ subfamilies. Representatives from different phylogenetic groups are shown. M embers in the $M$ eisl family include three genes in mouse, Meisl (U 33629, U 33630), Meis2 (four alternatively spliced isoform that do not affect the HD: 2a, U57343, AJ000504; 2b, U 68383, AJ000505; 2c, AJ000506; 2d, U 68384, AJ000507), and Meis3 (U 57344); three genes in human, MEIS1 (U 85707), PKNOX1 (U69727), and several ESTs defining the MEIS3 (F05816, H25643, R35310; two other short EST s probably have unspliced intron, D31072, T 10795); three genes in Xenopus laevis: meisl-1 (U 68386), meisl-2 (U68387), and meisl-3 (U68388). M ore distantly related members (not shown) include human TGIF (X89750), chicken AKR (U 25353), Arabidopsis ATH 1 (X80126), BELL1 (U 39944), and an EST (Z35398), a C. el egans EST (M 88963), yeast CU P9 (L36815), and a gene identified in the yeast genomic sequence (1723892). Residues identical to the $\mathrm{H}$ th sequence (top) are indicated by dots. The consensus sequence of classic HDs is shown at the bottom. The position of three extra residues in the TALE HD family is shown as dashes in the classic HD. Residues that are highly conserved among all HDs are indicated by an asterisk. (D). Comparison of the $\mathrm{MH}$ domain of $\mathrm{H}$ th to that of other members of the Meis-hth family. The arrowhead indicates the position of a 6-amino-acid (DGASAG) insertion in the mouse Meis3 protein.

shown). These patterns are very similar to those of nuclear Exd protein (data not shown; Gonzalez-Crespo and M orata 1995; Aspland and White 1997). Closer examination showed that the distribution of $\mathrm{Hth}$ and nuclear Exd generally coincide (Fig. 3J,K,L). Outside of the $\mathrm{H}$ th expression domain, Exd protein is present in low level and in the cytoplasm (Fig. 3K,L).

The mutant clonal phenotypes of hth resemble those of exd

All hth alleles, except 1422-4, are embryonic lethal with defects in segmentation, head involution, CN S, and PN S (Kurant et al. 1998). To examine the role of hth in imaginal devel opment, clones of hth mutant cells were generated by FLPase-induced mitotic recombination ( $\mathrm{Xu}$ and Rubin 1993). Three hth alleles (P2, P1- 115 , P1-K6-1) were studied. All of them showed si milar results. Clones on ventral head tissue (from antenna to postorbital bristles) resulted in ectopic eye formation (Fig. 4C,D), some of which are at the tip of a tubular outgrowth. However, within the compound eyes (Fig. 4D, arrow) as well as in the dorsal head structures, hth mutant clones do not show morphological phenotypes. When clones crossed the eye border, the shape of the eye could become distorted (not shown). In the eye-antenna discs of late third instar larvae bearing hth mutant clones, ectopic photoreceptor differentiation and local overgrowth could be detected. Consistent with the adult phenotypes, these ectopic photoreceptors were found only in the ventral margin of the eye-antenna disc (Fig. 4E,F). Clones in the dorsal margin of the eye disc did not lead to ectopic photoreceptor devel opment (Fig. 4F, arrowheads).

Mutant clones on the second or third antennal segments resulted in transformation to leg-like structure, with the larger clones giving a clear claw structure, indicative of a distal leg (Fig. 4A,B). M utant clones on the coxa, femur, or tibia often cause fusion of these leg segments, whereas those on the tarsal segments were morphologically normal. The structures affected by hth mutant clones are limited to the proximal antenna and leg segments, consistent with the expression of hth in the proximal region but not in the distal region of the antenna and leg discs. Clones on the mesonotum and abdomen did not have significant morphological phenotypes.

The adult clonal phenotypes are nearly identical to those of exd (Gonzalez-Crespo and Morata 1995; Rauskol b et al. 1995). Together with the above observation that the $\mathrm{Hth}$ and nuclear Exd have nearly identical distribution in the imaginal discs, these results suggest that hth and exd act in the same regulatory pathway. 

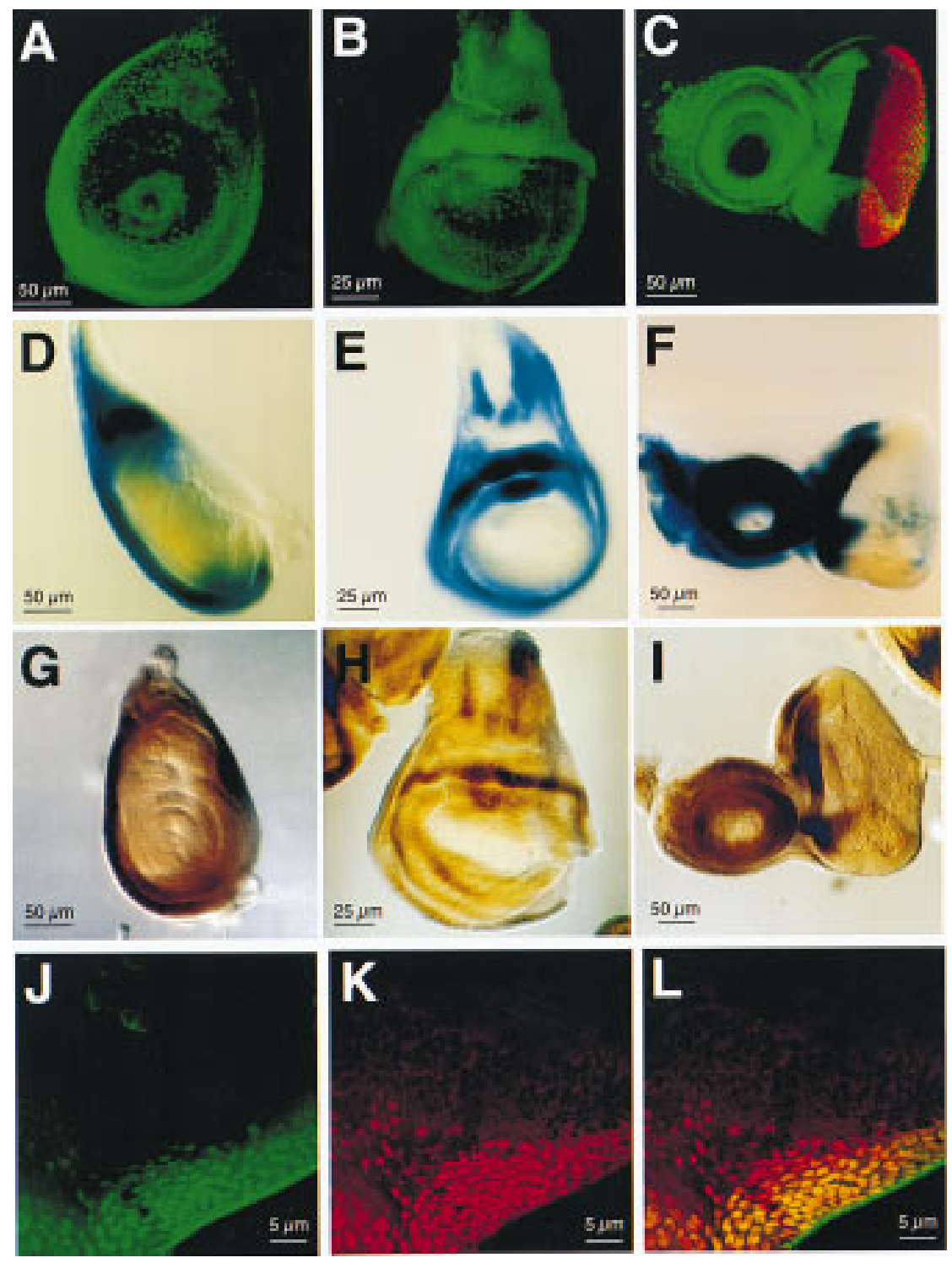

Figure 3. Expression pattern of hth in imaginal discs are similar to those of nuclear Exd. Expression pattern of hth in imaginal discs (leg disc, A,D,G; wing disc, $\mathrm{B}, \mathrm{E}, \mathrm{H}$; eye-antennea disc, $\mathrm{C}, \mathrm{F}, \mathrm{I})$ was detected by anti-Hth immunostaining in wild-type $(A-C)$, lacZ activity staining in the hth ${ }^{1422-4}$ enhancer trap line (D-F), and in situ hybridization in wild type (G-I). Anti-ELAV staining (red in C) was used to show the position of the photoreceptor neurons. Double staining of $\mathrm{H}$ th $(\mathrm{J})$ and Exd $(K)$ in the eye disc showed $\mathrm{Hth}$ colocalize with nuclear Exd (both channels merged in $\mathrm{L})$. Outside of the $\mathrm{Hth}$ domain, there is very weak cytoplasmic staining of Exd. The image is of the ventral-anterior margin of eye disc.
Hth activated Exd protein accumulation and nuclear localization

We checked the epi genetic relati onship of hth and exd by making hth mutant clones and examining whether exd expression was affected. In hth mutant clones in the eye disc, Exd protein was not detected (Fig. 4G-I). Thus, hth acts upstream of exd and is required for Exd protein expression or accumulation.

Ectopic expression experiments were performed to further study the relationship between hth and exd. The ectopic expression was achieved using the glass multimer reporter (GMR)-gal4 to drive UAS-hth or UASexd expression. The GMR-gal4 contains the yeast gal 4 gene driven by the GMR enhancer, which activates the gal4 gene in the region posterior to the morphogenic furrow (MF) of the eye disc (Hay et al. 1994), a region with no or very low levels of endogenous Exd or Hth expres- sion. Subsequently, the Gal 4 protein activates the expression of the transgene fused to the Gal4-responsive UAS (Brand and Perrimon 1993). GM R-gal4-induced expression of either $\mathrm{H}$ th or Exd had no significant effect on the adult eye morphology. This provided an ideal situati on to study the relationship of these two genes with the least complication.

When Exd was expressed ectopically, it was located in the cytoplasm rather than in the nucleus, where it is expected to exert its function as a transcriptional regulator (Fig. 5A-F). The cytoplasmic localization of Exd was not attributable to cloning artifact that prevented its nuclear import, as the ectopi c Exd was transported in the nucleus when Exd and $\mathrm{H}$ th were both induced (Fig. 5G$\mathrm{L})$. Thus, $\mathrm{H}$ th is sufficient to promote the nuclear localization of Exd protein.

Interestingly, when only UAS-hth was induced, Exd protein level was also elevated (Fig. 5M-R). The Hth- 
Figure 4. Clonal mutant phenotype of hth. hth mutant clones on the head cuticle were detected as $y$ and non-Sb bristles. Those in the compound eyes were detected as w. (A) A clone on the third antennal segment transformed the entire segment into distal leg structures with a claw (arrowhead). (B) Scanning electron microscope (SEM) picture of a similar clone showing antenna to leg transformation. (C) A clone ventral to the normal eye produced a small ectopic eye (arrowhead) at the tip of a tubular outgrowth. (D) A ventral clone caused ectopic eye development (arrowhead). The clone is entirely white, suggesting that the effect of hth mutation is cell-autonomous. However, clones within the compound eye did not have abnormal phenotypes (arrow). (E) Eye-antennal discs were double stained with phalloidin (green) and anti-ELAV (red) to reveal the location of the morphogenic furrow (arrow) and the photoreceptors, respectively. Ectopic photoreceptors (arrowhead) were detected in the ventral margin. (F) Eye-antennal discs were double stained with anti-Hth (green) and anti-ELAV (red) to reveal the position of hth mutant clones relative to the photoreceptors. A clone at the ventral margin of eye disc (arrow) caused ectopic photoreceptor development and local outgrowth. Two clones at the dorsal margin of eye disc (arrowheads) caused no ectopic photoreceptor formation. (GI)Eye-antennal discs were double stained with anti-Hth (G) and anti-Exd (H). An hth mutant clone (arrowhead) has no Hth staining (G) and no Exd staining (H). (I) A merged image of the $\mathrm{Hth}$ and Exd signals.
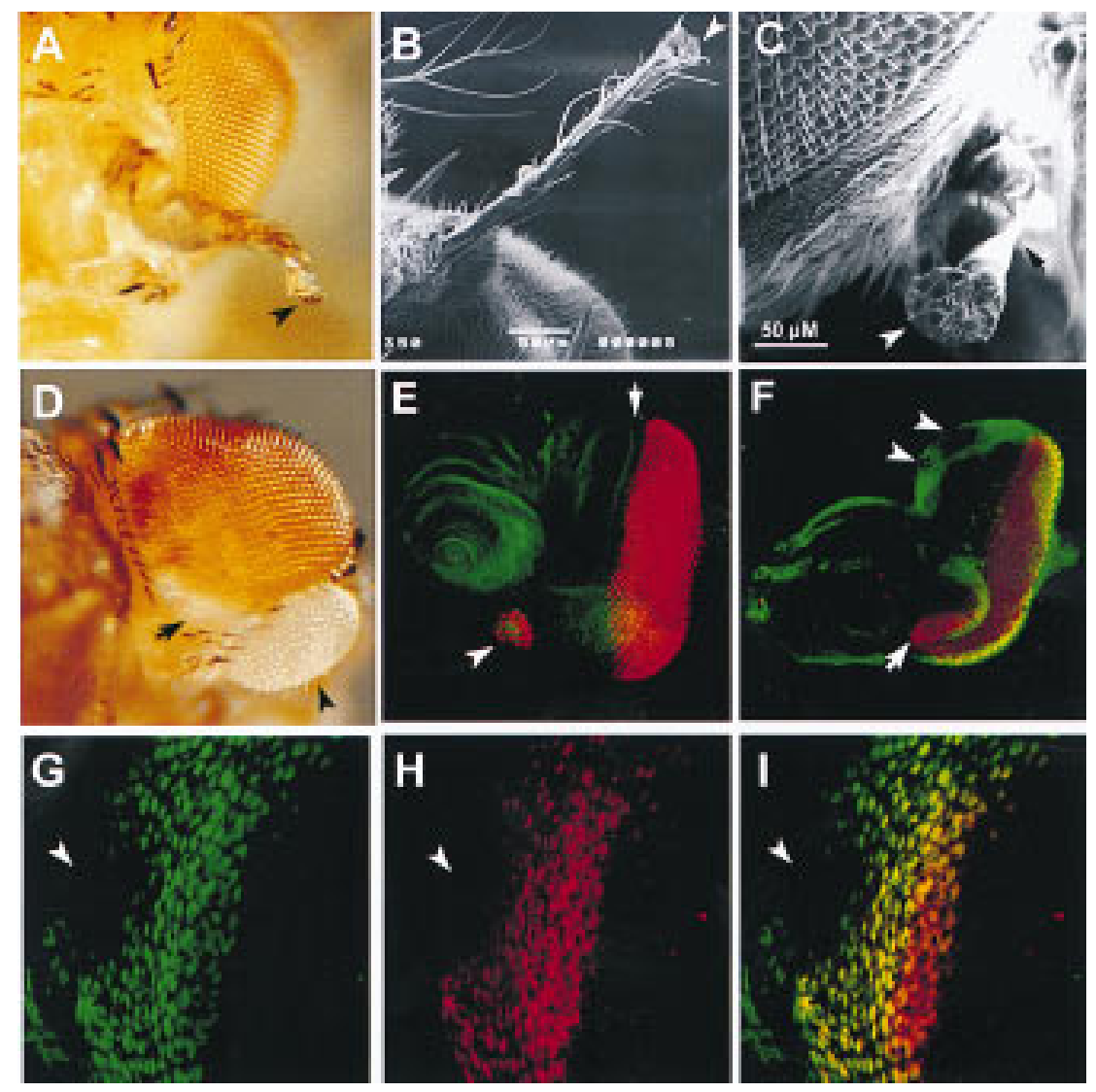

induced Exd appeared several rows of cells posterior to the $\mathrm{H}$ th-expressing front, and its level increased toward the posterior side (Fig. 5M-R). The gradual increase is consistent with the temporal order of GMR-gal4 expression; cells near the M F have just begun to express GM Rgal4, whereas more posteri or cells have expressed GM Rgal 4 for longer time. This is in contrast to the situation when both Hth and Exd were induced directly by GM Rgal4, where both proteins appeared simultaneously (Fig. 5G-L). Thus, the gradual increase of Exd indicated that the ectopically expressed $\mathrm{H}$ th is able to induce the nuclear accumulation of Exd protein.

Ectopic hth expression suppress normal eye development

Mutant hth or exd clones in the ventral head can result in ectopic eye formation. Both hth and exd are expressed in the region of the eye disc that develops into the head cuticle surrounding the compound eye (see Fig. 3C; see fate map in Haynie and Bryant 1986). Their expression seems to define the boundary of the eye field and therefore, one of their normal functions may be to prevent inappropriate or excessive eye development. To test this hypothesis, we expressed hth or exd cDN A ectopically (UAS-hth or UAS-exd) using dpp-gal 4 (Staehl ing-Hampton et al. 1994), which induced expression of the UAS fusion gene at the posterior margin of the eye disc where MF (the front of the posterior-to-anterior progression of retinal development) initiates. As expected, hth expression driven by dpp-gal 4 suppressed eye development completely (Fig. 6E). With weaker UAS-hth lines, the eyes were smaller and rough. $\mathrm{N}$ ot surprisingly, expression of exd driven by the same dpp-gal 4 did not have any effect (data not shown), presumably because the Exd protein cannot get into the nucleus in the absence of $\mathrm{Hth}$.

We then checked whether $\mathrm{H}$ th inhibited eye development by inhibiting MF movement. Ectopic clonal hth expression was induced using the flp-out and Gal4/UAS system (Brand and Perrimon 1993; Struhl and Basler 1993; Pignoni and Zipursky 1997). Thirty-one adult flies with clonal phenotype were analyzed. The hth-expressing clones located anterior to the MF disrupted the propagation of MF efficiently (Fig. 6). The disruption could be detected in the adult compound eyes as a scar running in the posterior-anterior direction (Fig. 6A-D) 


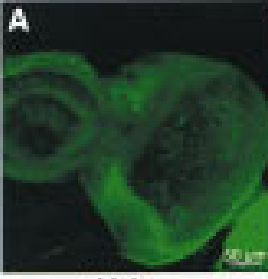

Hth

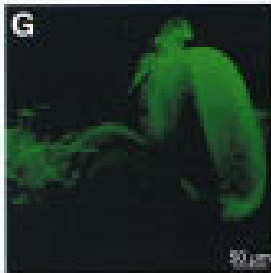

Hth

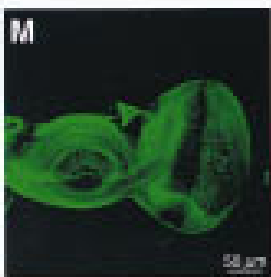

Hth

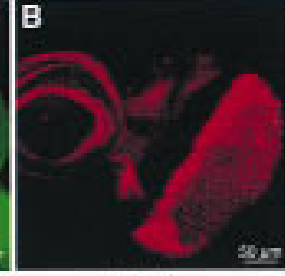

Exd

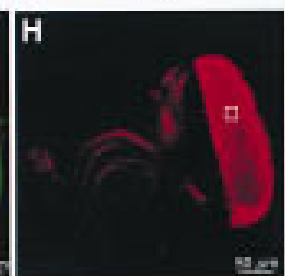

Exd

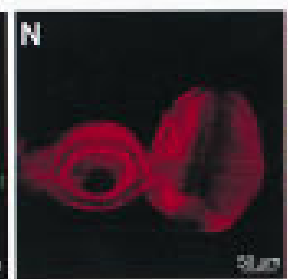

Exd

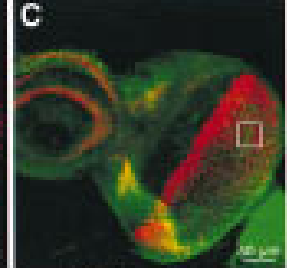

Hth + Exd

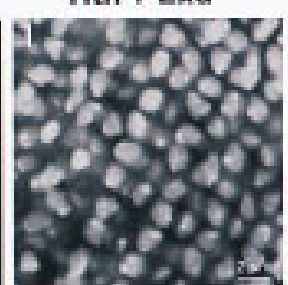

DNA

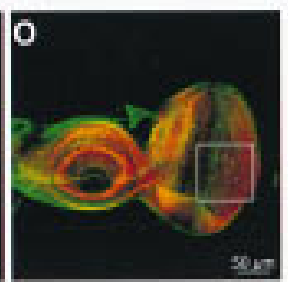

Hth + Exd

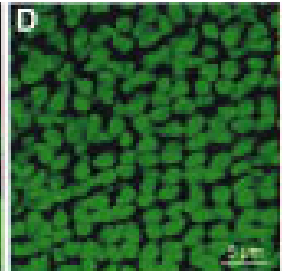

DNA

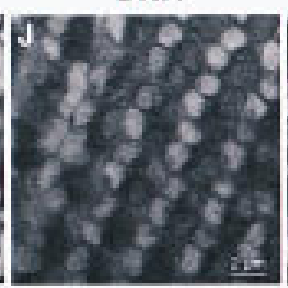

Hth

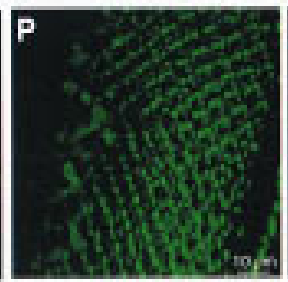

Hth

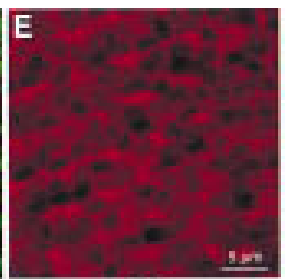

Exd

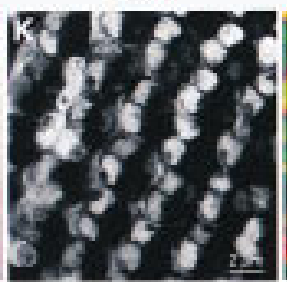

Exd

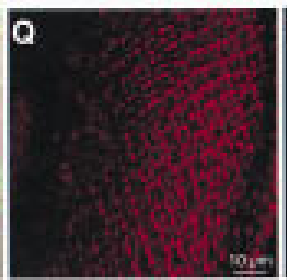

Exd

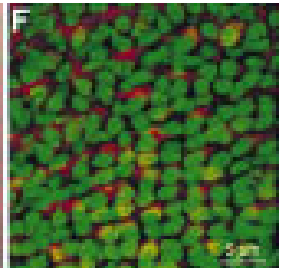

DNA + Exd

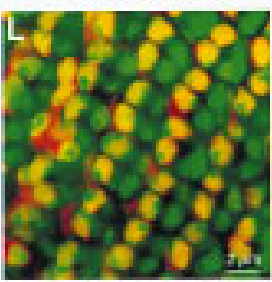

DNA + Exd

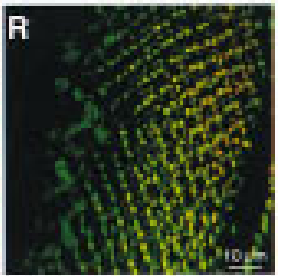

$\mathrm{Hth}+$ Exd

Figure 5. Hth ectopic expression induced the accumulation and nuclear transport of Exd. (A-F) Ectopically expressed Exd is located in the cytoplasm. Eye-antennal discs from UAS-exd/+; GMR-gal4/ + larvae were triple stained by anti-Hth, anti-Exd, and the DNA dye SYTOX. Ectopic Exd is induced in the GMR expression domain, posterior to the morphogenetic furrow (B). The merged image (C) showed that the ectopically induced Exd is not accompanied by $\mathrm{H}$ th. The endogenous $\mathrm{Hth}$ and Exd were colocalized (confirmed at higher magnification, not shown), although they were not expressed at the same relative level in all cells. (D-F) A region (boxed in C) of the GMR domain at higher magnification. (D) SYTOX Iabeling reveal ed the position of the nucleus. (E) Ectopically expressed Exd is primarily located in the cytoplasm. This is more clearly demonstrated in the merged image (F). (G-L) When Exd and $H$ th were coexpressed ectopically, both were located in the nucleus. Eye-antennal discs from UAS-exd/ +; GMR-gal4/+; UAS-hth/+larvae were triple stained by SYTOX, anti-Hth, and anti-Exd. Ectopic Hth (G), as well as Exd (H), was induced in the GMR domain, posterior to the furrow. (I-L) A region (boxed in $\mathrm{H}$ ) of the GMR domain at higher magnification. The ectopic $\mathrm{H}$ th and Exd were located in the nucleus. (L) M erged image of SYTOX (green) and anti-Exd (red) showed that Exd and DN A colocalize (yellow), except in a few dividing cells, where Exd is in the cytoplasm. $\mathrm{H}$ th and Exd staining is stronger in al ternating oblique rows of cells. This is probably attributable to the GMR specificity, as GMR-gal4-induced Ubx expression gave a similar pattern (not shown). (M-R) Ectopic expression of Hth resulted in an elevated level of Exd. The eye-antennal discs from GM R-gal 4/+; UAS-hth/ +; larvae were double stained for anti-Hth and anti-Exd. Ectopic induction of $\mathrm{Hth}$ also induced el evated levels of Exd in the GM R domain. A merged view $(\mathrm{O})$ showed that the Exd appears several rows of cells posterior to the anterior border of $\mathrm{H}$ th expression. This is clearer in a higher magnification (P-R).

and also in the eye discs of late third instar larvae (Fig. $6 \mathrm{E})$. In two cases, an eye was split into a dorsal and a ventral part, suggesting that a clone at the center of posterior margin can block the normal initiation of furrow, which may then result in the ectopic initiation of MF from the lateral margins. These results suggest that hth can suppress MF progression and possibly also MF initiation.

\section{Discussion}

hth activates Exd nuclear localization

We report the cloning and characterization of the hth gene in Drosophila. The Hth protein has an HD that in Drosophila is most similar to the HD of Exd. We had expected it to have functions similar to Exd (i.e., as a cofactor to HOX proteins), perhaps interacting with a different subset of HD proteins or have different effects on the DN A-binding specificity. It was surprising to find that the hth mutant phenotypes revealed by clonal analysis were almost identical to those of exd mutant clones (Gonzal ez-Crespo and Morata 1995; Rauskolb et al. 1995). The results suggested that hth and exd act in the same pathway. Our finding that hth activated Exd protein accumulation and nuclear localization provided a clear explanation of why the two genes have nearly identical mutant phenotypes.

The nuclear localization of Exd was shown to be regulated (Mann and Abu-Shaar 1996; Aspland and White 1997). Here we show that the Exd nuclear Iocalization can be controlled by hth. The expression domain of $\mathrm{Hth}$ correlates with the domain of nuclear Exd. Outside of the Hth expression domain, the low level of Exd appears to be present in cytoplasm (Fig. 3; Aspland and White 1997). When Exd is expressed ectopically without Hth, 


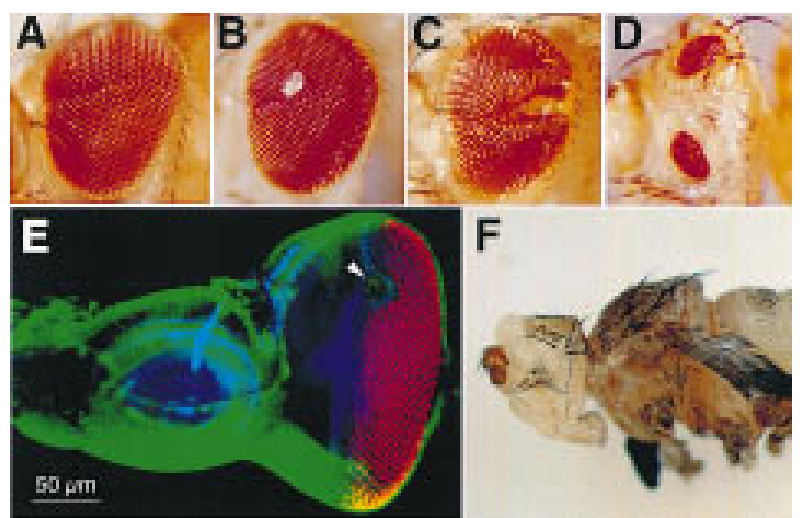

Figure 6. Ectopic expression of hth suppresses furrow progression/initiation and eye devel opment. Clonal hth ectopic expression were induced. Typical phenotypes in the adult compound eye includes a posterior-anterior scar (A), sometimes accompanied by local outgrowth (B). (C) In one case the scar is fused in the anterior end. (D) In two cases, the eye is split into a dorsal and a ventral small eye. All heads are oriented with anterior to the left and dorsal to the top. (E) The eye-antennal discs were triple stained with anti-Hth (green), anti-ELAV (red), and Phalloidin (blue). An ectopic hth-expressing clone (arrowhead) had inhibited M F progression and the subsequent photoreceptor differentiation. (F) dpp-gal4-induced hth expression completely abolished eye development.

Exd is located in the cytoplasm (Fig. 5). In hth mutant embryo, Exd is largely cytoplasmic (Kurant et al. 1998). These results indicated that hth is generally required for Exd nuclear localization. When Exd and Hth are coexpressed, both proteins were located in the nucleus (Fig. 5). These results indicated that at least in the eye disc, $\mathrm{H}$ th is also sufficient for Exd nuclear localization.

Exd has a basic region at the amino terminus of its HD that may serve as the NLS. Cytoplasmic retention of proteins with NLS can occur by modulation of phosphorylation at sites within or near the N LS, or through interaction with an inhibitor protein. Phosphorylation by CAM P-dependent protein kinase (PKA) and casein kinase II (CKII) have been shown to cause nuclear import of several mammalian proteins (for review, see Vandromme et al. 1996). We note that Exd has a potential phosphorylation site for PKA and for CKII, just upstream to the potential N LS. Whether these sites are phosphorylated and whether the phosphorylation trigger the nuclear import of Exd remains to be studied. Hth may activate Exd nuclear localization by indirectly affecting its phosphorylation state or its interaction with an inhibitory protein. Alternatively, $\mathrm{Hth}$ and Exd proteins may interact directly, and it is this interaction of two homeoproteins that facilitated their nuclear local ization.

The situation may be different in the leg discs. Exd is required for the development of the proximal parts of the legs but not for the distal parts (Gonzalez-Crespo and M orata 1995; Rauskolb et al. 1995), consistent with its expression in the corresponding regions in the leg discs. The same is also true for $h t h$. The region of expression is largely complementary to that of Distal-less (DII), another homeobox gene that is expressed in the central regi on of the leg discs and required for the corresponding distal part of the legs (Cohen and Jürgens 1989; Cohen et al. 1989). Ectopic expression of exd in the central region of leg disc caused elimination of distal leg structures (Gonzal ez-Crespo and M orata 1996). The phenotypic effect suggests that Exd may either enter the nucleus in the absence of $\mathrm{Hth}$, or alternatively, the cytopl asmic Exd may exert a dominant negative effect on DII function.

hth activates the nuclear accumulation of Exd protein exd mRN A is found uniformly in the imaginal discs (Flegel et al. 1993; Rauskol b et al. 1995). But Exd protein has a specific pattern of distribution (Gonzalez-Crespo and M orata 1995; A spland and White 1997), suggesting that exd may be regulated post-transcriptionally. In the imaginal discs the $\mathrm{Hth}$ distribution pattern correlates with the pattern of high level of Exd (Fig. 3). Loss-offunction hth mutant clones in the eye disc have no detectable Exd protein (Fig. 4), whereas ectopically expressed $\mathrm{Hth}$ in the eye disc induced the appearance of high level of Exd protein (Fig. 5). These results show that hth is both required and sufficient for Exd protein accumulation in the imaginal discs.

Because the high level of Exd correlated with Exd be ing nuclear, it is possible that the only posttranscriptional regulation is on nucl ear local ization. The effect of hth on Exd protein level may simply be a consequence of activated nuclear localization, which concentrated the cytoplasmic Exd into the nucleus. Alternatively, hth may regulate exd at an additional level: transcription, translation of endogenous exd mRNA, or post-translational events that stabilize the Exd protein. These alternatives remain to be resolved.

\section{hth and exd suppress eye development}

hth and exd mutant clones in the ventral part of the head caused growth of ectopic eye, suggesting that both genes normally function in suppressing inappropriate eye formation outside of the eye field. When hth was expressed in the devel oping eye (with the subsequent induction of Exd), the eye devel opment can be abolished completely, confirming the suppresive role of hth in eye development. When exd was expressed similarly, there was no effect, probably because the Exd protein cannot get into the nucleus in the absence of $\mathrm{Hth}$. Our results suggested that exd and hth act in the same regulatory pathway suppressing eye development. Hth may function solely through Exd, or Exd and Hth may act cooperatively in the nucleus.

One possible mode of $\mathrm{Hth} /$ Exd action in suppressing eye development is by activating Wg signaling, which suppresses the initiation of the MF in the eye disc ( $\mathrm{Ma}$ and Moses 1995; Treisman and Rubin 1995) or by suppressing Dpp signaling, which is required for MF initiation (Chanut and Heberlein 1997; Pignoni and Zipursky 1997). Hth is present in the periphery of the eye disc, 
weaker in the posterior margin, and stronger in the anterior half of the lateral margins. The distribution is consistent with a role in suppressing dpp expression (expressed in the posterior and lateral margins but not in the most anterior of the lateral margins) and activating wg expression (expressed in the anterior half of the lateral margins). hth mutant clones located in the ventral region of the head can cause ectopic eye formation, whereas clones in the dorsal region have no effect. This correlates with the stronger expression and inhibitory effect of wg in the dorsal margin (Treisman and Rubin 1995). hth-Expressing clones can block the propagation and possibly the initiation of the MF (Fig. 6). These effects are consistent with either a loss of Dpp function or an enhanced Wg function.

A nother possible mode of $\mathrm{Hth}$ /Exd action is by interacting negatively with a nuclear protein, which is required for eye development. Similar mode of action has been proposed for proboscipedia (pb; Bennassayag et al. 1997). U biquitous expression of a mutant $\mathrm{Pb}$ protein can suppress eye devel opment. The effect is independent of DN A binding by $\mathrm{Pb}$ and was suggested to be attributable to perturbed interaction with other proteins. The many nuclear factors required for eye development (eyeless, dachshund, sine oculis, and eyes absent; see Bonini and Choi 1995) are candidates for this suppressive interaction with Exd or Hth.

\section{Function of $\mathrm{Hth}$}

Several pieces of evidence suggest that hth can interact with Hox genes, similar to exd. In the hth mutant embryo, the expression of a number of Hox genes were not affected, but their functions were affected; thus hth can function as a homeotic cofactor (Rieckhof et al. 1997; Kurant et al. 1998). hth and $\mathrm{Dfd}^{1}$ (a gain-of-function mutation of the Deformed HOX gene) double mutants have synergistic effects on eye development (C.-Y. Pai and Y.H. Sun, unpubl.), suggesting that the two proteins may interact. In retrovirus-induced myeloid leukemia in the $\mathrm{BXH}-2$ mice, Meisl is often coactivated with either Hoxa7 or Hoxa9, suggesting that Meis1 may cooperate with these two HOX proteins in leukemia formation (N akamura et al. 1996b). The mammalian link suggests that in Drosophila Hth may interact with Antp and AbdB (the homologs of Hoxa7 and Hoxa9, respectively; Burglin 1994).

Because Hth activates Exd nucl ear localization, it may exert the above described functions solely through Exd. In vitro studies have shown that Exd can have DNAbinding activity and can interact with HOX proteins, all in the absence of Hth. Does Hth have its own function other than bringing Exd into the nucleus? Hth has a HD similar to that of Pbx and Exd. Eight of the 13 highly conserved residues in all homeodomains are conserved in $\mathrm{H}$ th. Another three residues are identical to those in the Pbx/Exd family (Fig. 2). The high degree of conservation suggests that the HD is functional. Whether $H$ th can serve as a homeotic cofactor or transcription factor independent of Exd is an interesting question awaiting further analysis.

Hth and Meis proteins define a new HD family and a $\mathrm{MH}$ domain

The hth gene is a member of the Meis gene family, including three genes in human, mouse, and Xenopus (Fig. 2; Nakamura et al. 1996a; Chen et al. 1997; Smith et al. 1997; Steelman et al. 1997). Our study of hth is the first demonstration of a physiological function for this highly conserved gene family. Hth has two regions highly homologous to other members of the Meis family. The $\mathrm{N}^{\prime}$ homology region defines the $\mathrm{MH}$ domain, which is found only in the vertebrate Meis family and in $\mathrm{H}$ th. This domain has previously eluded recognition because of the high degree of overall homology in the vertebrate Meis gene family. Its high conservation from vertebrates to Drosophila suggests an important, but as yet unknown, function. The $C^{\prime}$ region includes and extends slightly beyond the HD. The HD defines a Meis family in the TALE superfamily of HDs, characterized by three extra amino acids in the first $\alpha$ helix.

Meisl was isolated as a hot spot of retroviral insertions in myel oid leukemia arising in the $\mathrm{BXH}-2$ mice (M oskow et al . 1995). Activation of Meisl expression is correlated with leukemia formation (Moskow et al. 1995; Nakamura et al. 1996b). The human MEISI is al so expressed in a subset of myeloid leukemia cell lines (Smith et al. 1997). The exd homolog PBX 1 was similarly identified as a fusion partner with the transcription factor E2A found in human pre-B-cell leukemias (Kamps et al. 1990; N ourse et al. 1990). Our results suggest that the vertebrate Meisl genes may have a function similar to its Drosophila homolog in regulating Pbx nuclear localization, and that misexpression of Meisl may cause leukemia by activating the nuclear localization of Pbx proteins.

\section{Materials and methods}

Fly stocks

P1 and P2 enhancer trap lines have been described previously (Sun et al. 1995). P1 15, P1-K1-8, P1-K6-1 are lethals derived from P1 after induction of P[lacW] mobilization. H321 and J186 are two EM S-induced allel es of dtl (Sal zberg et al. 1994). 1422-4 and 1323-7 are two P[lacW]-tagged dtl alleles, also with the posterior eye pigmentation phenotype (Salzberg et al. 1997). A P[Pz]-tagged lethal mutation I(3)05745 was mapped to 86C by the Berkeley Drosophila Genome Project (Gelbart et al. 1997). Complementation tests showed that all of these lethal mutations are allelic to hth (Jürgens et al. 1984). hth mutants were provided by Richard Mann (Columbia University, New York, NY).

P[GM R-gal4] was from Hui-yun Chang (Don Ready, Purdue University, West Lafayette, IN ). The FLPase source y w P[ry ${ }^{+}$, hs-FLP] ${ }^{22}$; CXD/TM3, Sb Ser e was from Tze-bin Chou ( $\mathrm{Na}$ tional Taiwan University, Taipei). y w; P[ry; hs-neo; FRT]82B $\mathrm{P}\left[\mathrm{w}^{+\mathrm{m}}\right.$; hs- $\left.\pi \mathrm{M}\right] 90 \mathrm{E} \mathrm{Sb}{ }^{63 \mathrm{~b}} \mathrm{P}\left[\mathrm{ry}^{+} ; \mathrm{y}^{+}\right] / \mathrm{TM} 6 \mathrm{~B}$ (Xu and Rubin 1993) and dpp-gal 4 (Staehling-Hampton et al. 1994) were from the Bloomington Stock Center (IN). P[UAS-exd] was from G. M o- 
rata (Gonzalez-Crespo and Morata 1996). y w P[w ${ }^{+}$; act-FRTCD2-FRT-gal4] was from F. Pignoni (Pignoni and Zipursky 1997). y w; [ry+; hs-neo; FRT]82B hth lines were obtained by selecting recombinants of $y w^{2}$ P $\left[r^{+} ;\right.$hs-neo; FRT $] 82 B P\left[w^{+m}\right.$; hs- $\pi \mathrm{M}$ ]90E and hth alleles P2, P1- $\Delta 15$, and P1-K6-1. Mutations are described in Lindsley and Zimm (1992) and FlyBase (Gel bart et al. 1997).

\section{Cloning and molecular analysis of hth}

Southern blots showed that there is a single $\mathrm{P}[\mathrm{lacW}]$ in the enhancer trap P1 line. A 2.1-kb fragment (pSY 46) was cloned by plasmid rescue (Bier et al. 1989) from EcoRI-digested P1 genomic DN A. Southern blots using this fragment as a probe showed a different pattern in P1 from wild type. The fragment was used to screen a fly genomic $\lambda$ Ch4A library (M aniatis et al. 1978), from which a clone ( $\lambda S Y 46)$ containing a $13.4-\mathrm{kb}$ insert was isolated (Fig. 1A). The restriction map of $\lambda S Y 46$ is consistent with the map deduced from genome bl ot analysis. Genome bl ot also showed that the $\lambda S Y 46$ clone does not contain repetitive elements. It was used to screen an imaginal disc cDN A library provided by N. Brown (Brown and Kafatos 1988). Eleven positive clones were isolated. Restriction mapping and partial sequencing classified the CDN A clones into two nonoverlapping groups. Group I is represented by a single clone (clone 1 ) of $1068 \mathrm{bp}$. Its $3^{\prime}$ end is 260 bp from the P[lacW] insert site. Group II consists of 10 overlapping clones, 8 of which are independent clones. Clones 1, 4, 5, and 7 have been sequenced completely in both strands, the others were checked by partial sequencing, restriction mapping, and PCR. The TNT Iysate coupled transcription/ translation kit (Promega) was used to check the protein-coding capability of the cDN A clones. Additional genomic clones were isolated using the group II CDNA as a probe.

The group II cDN A clones contain an ORF of 1461 bp. N one of the first six in-frame ATGs have flanking sequences that match the consensus for ribosome binding site in Drosophila $\left(C_{/ A} A_{/ G} A_{/ C} A_{/ C}\right.$ AUG; Dalphin et al. 1996) or in vertebrates (Kozak 1984). The predicted molecular masses of the encoded polypeptides are 52.8, 51.2, 50.5, 47.9, 46.9, and 43.9 kD. In vitro translation of clones 5 and 7 gave a protein band of $\sim 55 \mathrm{kD}$ (data not shown), suggesting that the first ATG may be used as the translation start site.

The $5^{\prime}$ end sequence of clone 7 (GACAGTGT) matched well with the consensus of Drosophila transcription initiator (Arkhipova 1995). However, its upstream genomic sequence (data not shown) did not have a TATA box. Sequence at the $5^{\prime}$ end of clone 5 did not match with the initiator el ement but has a consensus TATA box (TTATAAACC, -32 to -24 relative to the $5^{\prime}$ end of clone 5) (Arkhipova 1995). It is not clear whether there are two potential transcription initiation sites. The $5^{\prime}$ end sequence of the other CDNA clones did not match with the TATA box or initiator and therefore, probably resulted from incomplete CDNA synthesis. The group II CDNA clones revealed four different polyadenylation sites, none affecting the ORF.

By comparing the sequences of cDNAs with parts of the genomic fragments, one exon-intron junction has been identified after the +14 position in the ORF (Fig. 1A,B, arrow). A 45-bp segment was present in clones $3,4,7,8,9$, and 10 , but absent in clones 2 and 5 (Fig. 1B). The boundary sequences did not fit the consensus of $5^{\prime}$ and $3^{\prime}$ splice junctions (GT and AG, respectively; M ount 1982), nor those of the minor intron class (AT and AC; Jackson 1991; Hall and Padgett 1994). We do not know whether it is an al ternatively spliced exon. Interestingly, several cDN A clones isolated from an embryonic library were analyzed and all contained 45 bp (data not shown). Clone 4 is unique in that it contained two segments (Fig. 1B, open bar) that do not hybridize with the other clones. The sequence at the junctions (ATTG|GTGA ... .ACAG|GTTC . . .CAG|GTAA . . . ; Fig 1B, arrowheads) matched perfectly with the consensus splice junction sites, suggesting that these are unspliced intron. The first unspliced intron immediately generated a stop codon after residue 415; therefore, the protein encoded by clone 4 cDNA is truncated in the HD. Whether this isoform is just an aberrant splice product or plays a regulatory role is not clear.

A 2.2-kb plasmid can be recovered from the P1-K1-8 mutant by plasmid rescue using EcoRI digest. Sequence and Southern blot analysis showed that a region starting $75 \mathrm{bp} 3^{\prime}$ from the EcoRI site to the proximal end of the P[lacW] (including the HindlII site) has been deleted in P1-K1-8 (Fig. 1A).

\section{UAS-hth and hs-hth transgenic flies}

A PCR-amplified fragment containing the complete hth ORF was first inserted into the BamHI site in pBluescript (SK+) vector (Stratagene), then was recut out by EcoRI and Xbal and inserted between EcoRI and Xbal sites of pP[UAST] (Brand and Perrimon 1993) and pP[CaSpeR-hs/act] (Thummel and Pirrotta 1992). They were used to generate transgenic flies using the traditional germ-line transformation procedure (Rubin and Spradling 1982). Multiple independent transformants were obtained for each construct. Two lines with P[CaSpeR-hs-hth] on the $\mathrm{X}$ chromosome, $\mathrm{P}\left[\right.$ hs-hth ${ }^{10}, \mathrm{P}[\text { hs-hth }]^{20}$, and one line with $\mathrm{P}[\mathrm{C} \text { aSpeR-hs-hth] on the second chromosome, P[hs-hth }]^{4}$, were tested for their ability to rescue the lethality of several hth allel es (P2, 1422-4, P1- $\Delta 15$, K1-8). P[hs-hth]/ +; hth/TM3, Sb Ser e flies were maintained at $25^{\circ} \mathrm{C}$. Eggs from these flies were collected every $12 \mathrm{hr}$ and were heat shocked in $37^{\circ} \mathrm{C}$ water bath for $15 \mathrm{~min}$ every $12 \mathrm{hr}$ throughout development. Rescued flies were detected as non-Sb flies. Rescue to adulthood was detected only in the weak hth ${ }^{1422-4}$ allele. Whether the other alleles can be rescued partially has not been examined.

\section{Clonal analysis and ectopic expression}

To generate mosaic flies with hth mutant clones, y w [ry ${ }^{+}$, hsFLP]; P[ry; ${ }^{+}$hs-neo; FRT ]82B P[w ${ }^{+m}$; hs- $\left.\pi \mathrm{M}\right] \mathrm{Sb}^{63 \mathrm{~b}} \mathrm{P}\left[\mathrm{ry}^{+} ; \mathrm{y}^{+}\right] /$ CXD were crossed with y w; P[ry ; hs-neo; FRT]82B hth/TM3, $\mathrm{Sb}$ Ser e. Embryos were collected every $12 \mathrm{hr}$ and were incubated for $1 \mathrm{hr}$ in $37^{\circ} \mathrm{C}$ waterbath $24-36 \mathrm{hr}$ AEL. The hth alleles used included P2, P1- $\Delta 15$, and P1-K6-1. All gave similar results. A total of 271 mutant clones on the adult head were scored: 63 on the second or third antennal segment, 120 on the ventral head structures including vibrissae (22), gena (36), postgena (38), and lower postorbital bristles (24), 72 within the compound eye, and 16 on the dorsal head structures including verticle bristles (11), ocellus (2), and upper postorbital bristles (3).

To induce random hth expression clones, y w P[ry; hsFLP] ${ }^{22}$; UAS-hth/TM3, Sb Ser e flies were crossed with P[actFRT-CD2-FRT-gal4]. Larvae 24-36 hr AEL were incubated for $1 \mathrm{hr}$ in a $37^{\circ} \mathrm{C}$ water bath. A bout 300 adults were examined and 31 had clonal phenotype affecting the eye. Because of the lack of marker, the exact extent of the hth-expressing clones cannot be determined in the adult.

\section{Histochemistry}

Digoxigenin-labeled RNA probe was used for whole mount in situ hybridization of imaginal discs (Theisen et al. 1996). Ratanti-Exd antibody was from G. Morata (Gonzalez-Crespo and M orata 1995). Rabbit-anti-Hth antisera were prepared from the Escherichia coli expressed $\mathrm{H}$ th protein with an amino-terminal 
poly-(His) tag. The antisera detected only one protein species $(\sim 55 \mathrm{kD})$ on the immunobl ot of Drosophila embryo extract. For anti-Exd and anti-Hth immunofluorescence staining, imaginal discs were dissected from late third instar larvae in PBS (137 mM $\left.\mathrm{NaCl}, 2.68 \mathrm{~mm} \mathrm{KCl}, 8.1 \mathrm{~mm} \mathrm{Na}_{2} \mathrm{HPO}_{4}, 1.47 \mathrm{~mm} \mathrm{KH}_{2} \mathrm{PO}_{4}\right)$. Discs were incubated in fixation solution (4\% paraformaldehyde, $0.2 \%$ Triton X-100, PBS) for $20 \mathrm{~min}$. After several washes with PBT $(0.2 \%$ Triton X-100, PBS), discs were transferred into PBTS ( $10 \%$ bovine serum, PBT) for $1 \mathrm{hr}$. Then, discs were incubated with staining solution (primary antibody, PBTS) overnight at $4^{\circ} \mathrm{C}$. After several washes with PBT to remove primary antibodies, discs were incubated with Cy5- or Cy3-labeled secondary antibodies for $1 \mathrm{hr}$. In those experiments that have DN A counterstaining, SYTOX (Molecular Probes Co.) was added to the secondary antibody staining solution to $0.1 \mu \mathrm{m}$. After several washes with PBT, discs were mounted in mounting solution [90\% glycerol, 0.22 м 1,4-diazabicyclo-(2.2.2)octane] and viewed under a Zeiss confocal microscope.

\section{Acknowledgments}

We thank Hui-yun Chang, Franscesca Pignoni, Tze-bin Chou, Pradip Sinha, Gines M orata, and the Bloomington Stock Center for providing the fly stocks, and Gines M orata for antibody. We are grateful for valuable suggestions from Cheng-Ting Chien and Don Ready, to Chen-shu Hsieh for preparing fly food, and to Chiou-Yang Tang for maintaining fly stocks. This study was supported by grants to $\mathrm{Y}$.H.S. from the $\mathrm{N}$ ational Science Council (N SC-84-2311-B-001-087, N SC-86-2313-B-001-003, N SC-872311-B-001-106) and the Academia Sinica, Taiwan, Republic of China, and a grant from the Israel Cancer Association to A.S. C.-Y.P. is supported by a $\mathrm{N}$ ational Science Council postdoctoral fellowship.

The publication costs of this article were defrayed in part by payment of page charges. This article must therefore be hereby marked "advertisement" in accordance with 18 USC section 1734 solely to indicate this fact.

\section{Note added in proof}

Sequence of the hth CDNA clones 7 and 5 have been deposited in GenBank (accession nos. AF035825 and AF036584, respectively).

\section{References}

Arkhipova, I.R. 1995. Promoter elements in Drosophila melanogaster reveal ed by sequence analysis. Genetics 139: 13591369.

Aspland, S.E. and R.A. White. 1997. N ucleocytoplasmic localisation of extradenticle protein is spatial ly regulated throughout devel opment in Drosophila. Devel opment 124: 741-747.

Bennassayag, C., L. Seroude, M. Boube, M. Erard, and D.L. Cribbs. 1997. A homeodomain point mutation of the Drosophila proboscipedia protein provokes eye loss independently of homeotic function. Mech. Dev. 63: 187-198.

Bier, E., H. Vaessin, S. Shepherd, K. Lee, K. M cCall, S. Barbel, L. Ackerman, R. Carretto, T. Uemura, E. Grell et al. 1989. Searching for pattern and mutation in the Drosophila genome with a P-lacZ vector. Genes \& Dev. 3: 1273-1287.

Bonini, N.M. and K.-W. Choi. 1995. Early decisions in Drosophila eye morphogenesis. Curr. O pin. Genet. Dev. 5: 507515.

Brand, A.H. and N. Perrimon. 1993. Targeted gene expression as a means of altering cell fates and generating dominant phe- notypes. Development 118: 401-415.

Brown, N.H. and F.C. Kafatos. 1988. Functional cDN A libraries from Drosophila embryos. J. Mol. Biol. 203: 425-437.

Burglin, T.R. 1994. A comprehensive classification of homeobox genes. In Guidebook to the homeobox genes (ed. D. Duboule), pp. 25-71. Oxford U niviversity Press, Oxford, UK.

Chan, S.K. and R.S. Mann. 1996. A structural model for a homeotic protein-extradenticle-DN A complex accounts for the choice of HOX protein in the heterodimer. Proc. Natl. Acad. Sci. 93: 5223-5228.

Chang, C.P., L. Brocchieri, W.F. Shen, C. Largman, and M.L. Cleary. 1996. Pbx modulation of Hox homeodomain aminoterminal arms establishes different DNA-binding specificities across the Hox locus. Mol. Cell. Biol. 16: 1734-1745.

Chanut, F. and U. Heberlein. 1997. Role of decapentaplegic in initiation and progression of the morphogenetic furrow in the developing Drosophila retina. Development 124: 559567.

Chen, H., C. Rossier, Y. N akamura, A. Lynn, A. Chakravarti, and S.E. Antonarakis. 1997. Cloning of a novel homeoboxcontaining gene, PKNOX1: and mapping to human chromosome 21q22.3. Genomics 41: 193-200.

Cohen, S.M. and G. Jürgens. 1989. Proximal-distal pattern formation in Drosophila: Cell autonomous requirement for Distal-less gene activity in limb development. EMBO J. 8: 2045-2055.

Cohen, S.M ., G. Bronner, F. Kuttner, G. Jürgens, and H. Jackle. 1989. Distal-less encodes a homeodomain protein required for limb development in Drosophila. Nature 338: 432-434.

Dalphin, M.E., C.M. Brown, P.A. Stockwell, and W.P. Tate. 1996. TransTerm: A database of translational signals. Nucleic Acids Res. 24: 216-218.

Flegel, W.A., A.W. Singson, J.S. M argolis, A.G. Bang, J.W. Posakony, and C. Murre. 1993. Dpbx, a new homeobox gene cl osely related to the human proto-oncogene pbx1 molecular structure and developmental expression. Mech. Dev. 41: $155-161$.

Gelbart, W.M., M. Crosby, B. Matthews, W.P. Rindone, J. Chillemi, S. Russo-Twombly, D. Emmert, M. Ashburner, R.A. Drysdale, E. Whitfield, G.H. Millburn, A. de Grey, T. Kaufman, K. Matthews, D. Gilbert, V. Strelets, and C. Tolstoshev. 1997. FlyBase: A Drosophila database. The FlyBase consortium. Nucleic Acids Res. 25: 63-66.

Gonzalez-Crespo, S. and G. Morata. 1995. Control of Drosophila adult pattern by extradenticle. Development 121: 2117-2125.

- - - 1996. Genetic evidence for the subdivision of the arthropod limb into coxopodite and telopodite. Development 122: 3921-3928.

Hall, S.L. and R.A. Padgett. 1994. Conserved sequences in a class of rare eukaryotic nuclear introns with non-consensus splice sites. J. Mol. Biol. 239: 357-365.

Hay, B.A., T. Wolff, and G.M. Rubin. 1994. Expression of baculovirus P35 prevents cell death in Drosophila. Development 120: 2121-2129.

Haynie, J.L. and P. Bryant. 1986. Development of the eye-antenna imaginal disc and morphogenesis of the adult head in Drosophila melanogaster. J. Exp. Zool. 237: 293-308.

Jackson, I.J. 1991. A reappraisal of non-consensus mRN A splice sites. Nucleic Acids Res. 19: 3795-3798.

Jürgens, G., E. Wieschaus, C. N üsslein-Volhard, and H. Kluding. 1984. Mutations affecting the pattern of the larval cuticle in Drosophila melanogaster. II. Zygotic loci on the third chromosome. Wilhelm Roux. Arch. Dev. Biol. 193: 283-295.

Kamps, M.P., C. Murre, X.H. Sun, and D. Baltimore. 1990. A new homeobox gene contributes the DNA binding domain 
of the $t(1 ; 19)$ translocation protein in pre-B ALL. Cell 60: 547-555.

Kozak, M. 1984. Compilation and analysis of sequences upstream from the translational start site in eukaryotic mRN As. Nucleic Acids Res. 12: 857-872.

Kurant, E., C.-Y. Pai, R. Sharf, N. Halachmi, Y.H. Sun, and A. Salzburg. 1998. dorsotonal/homothorax, the Drosophila homologue of meisl, interacts with extradenticle in patterning of the embryonic PNS. Development (in press).

Lindsley, D.L. and G.G. Zimm. 1992. The genome of Drosophila melanogaster. Academic Press, San Diego, CA.

Lu, Q. and M.P. Kamps. 1996. Structural determinants within $\mathrm{Pbx} 1$ that mediate cooperative DN A binding with pentapeptide-containing $\mathrm{Hox}$ proteins: proposal for a model of a Pbx1Hox-DN A complex. Mol. Cell. Biol. 16: 1632-1640.

Lu, Q., P.S. Knoepfler, J. Scheele, D.D. Wright, and M .P. Kamps. 1995. Both Pbx1 and E2A-Pbxl bind the DNA motif ATCAATCAA cooperatively with the products of multiple murine Hox genes, some of which are themselves oncogenes. Mol. Cell. Biol. 15: 3786-3795.

$\mathrm{Ma}, \mathrm{C}$. and K. Moses. 1995. Wingless and patched are negative regulators of the morphogenetic furrow and can affect tissue polarity in the devel oping Drosophila compound eye. Development 121: 2279-2289.

Maniatis, T., R.C. Hardison, E.R. Lacy, J. Lauer, C. O'Connell, D. Quon, G.K. Sim, and A. Efstratiadis. 1978. The isolation of structural genes from libraries of eucaryotic DNA. Cell 15: 687-701.

Mann, R.S. 1995. The specificity of homeotic gene function. BioEssays 17: 855-863.

Mann, R.S. and M. A bu-Shaar. 1996. N uclear import of the homeodomain protein extradenticle in response to $\mathrm{Wg}$ and $\mathrm{Dpp}$ signalling. Nature 383: 630-633.

M oskow, J.J., F. Bullrich, K. Huebner, I.O. Daar, and A.M. Buchberg. 1995. Meis1: A PBX1-related homeobox gene involved in myeloid leukemia in BXH-2 mice. Mol. Cell. Biol. 15: 5434-5443.

Mount, S.M. 1982. A catal ogue of splice junction sequences. Nucleic Acids Res. 10: 459-472.

N akamura, T., N.A. Jenkins, and N.G. Copeland. 1996a. Identification of a new family of Pbx-related homeobox genes. Oncogene 13: 2235-2242.

N akamura, T., D.A. Largaespada, J.D. Shaughnessy, Jr., N.A. Jenkins, and N.G. Copeland. 1996b. Cooperative activation of Hoxa and Pbxl-related genes in murine myeloid leukaemias. Nature Genet. 12: 149-153.

Nigg, E.A. 1997. N ucleocytoplasmic transport: Signals, mechanisms and regulation. Nature 386: 779-787.

N ourse, J., J.D. M ellentin, N. Galili, J. Wilkinson, E. Stanbridge, S.D. Smith, and M.L. Cleary. 1990. Chromosomal translocation $t(1 ; 19)$ results in synthesis of a homeobox fusion $\mathrm{mRN} A$ that codes for a potential chimeric transcription factor. Cell 60: 535-545.

Peifer, M. and E. Wieschaus. 1990. Mutations in the Drosophila gene extradenticle affect the way specific homeodomain proteins regulate segmental identity. Genes \& Dev. 4: 12091223.

Phelan, M.L., I. Rambaldi, and M.S. Featherstone. 1995. Cooperative interactions between HOX and PBX proteins mediated by a conserved peptide motif. Mol. Cell. Biol. 15: 39893997.

Pignoni, F. and S.L. Zipursky. 1997. Induction of Drosophila eye development by Decapentaplegic. Development 124: 271278.

Pinsonneault, J., B. Florence, H. Vaessin, and W. McGinnis. 1997. A model for extradenticle function as a switch that changes HOX proteins from repressors to activators. EMBO J. 16: 2032-2042.

Rauskolb, C., M. Peifer, and E. Wieschaus. 1993. extradenticle, a regulator of homeotic gene activity, is a homolog of the homeobox-containing human proto-oncogene pbx1. Cell 74: 1101-1112.

Rauskolb, C., K.M. Smith, M. Peifer, and E. Wieschaus. 1995. extradenticle determines segmental identities throughout Drosophila development. Development 121: 3663-3673.

Rieckhof, G., F. Casares, H.D. Ryoo, M. Abu-Shaar, and R.S. $M$ ann. 1997. N uclear transl ocation of Extradenticle requires homothorax, which encodes an Extradenticlerelated homeodomain protein. Cell 91: 171-183.

Rubin, G.M. and A.C. Spradling. 1982. Genetic transformation of Drosophila with transposable element vectors. Science 218: 348-353.

Salzberg, A., D. D'Evelyn, K.L. Schulze, J.K. Lee, D. Strunpf, L. Tsai, and H.J. Bellen. 1994. Mutations affecting the pattern of the PNS in Drosophila reveal novel aspects of neuronal devel opment. Neuron 13: 269-287.

Salzberg, A., S. Prokopenko, Y. He, P. Tsai, P. Deak, M. Pal, P. Maroy, D.M. Glover, and H.J. Bellen. 1997. P element insertion alleles of essential genes on the third chromosome of Drosophila melanogaster: Mutations affecting embryonic PN S devel opment. Genetics 147: 1723-1741.

Smith, Jr., J.E., J.A. Bollekens, G. Inghirami, and K. Takeshita. 1997. Cloning and mapping of the MEIS1 gene, the human homolog of a murine leukemogenic gene. Genomics 43: 99103.

Staehling-Hampton, K., P.D. Jackson, M . Clark, A.H. Brand, and F.M. Hoffmann. 1994. Specificity of bone morphogenetic protein-related factors: Cell fate and gene expression changes in Drosophila embryos induced by decapentaplegic but not 60A. Cell Growth Differ. 5: 585-593.

Steelman, S., J.J. Moskow, K. Muzynski, C. N orth, T. Druck, J.C. Montgomery, K. Huebner, I.O. Daar, and A.M. Buchberg. 1997. Identification of a conserved family of Meis1related homeobox genes. Genome Res. 7: 142-156.

Struhl, G., and K. Basler. 1993. Organizing activity of wingless protein in Drosophila. Cell 72: 527-540.

Sun, Y.H., C.-J. Tsai, M .M. Green, J.-L. Chao, C.-T. Yu, T.J. Jaw, J.-Y. Y eh, and V.N. Bolshakov. 1995. white as a reporter gene to detect transcriptional silencers specifying position-specific gene expression during Drosophila melanogaster eye development. Genetics 141: 1075-1086.

Theisen, H., T.E. Haerry, M.B. O'Connor, and J.L. Marsh. 1996. Devel opmental territories created by mutual antagonism between Wingless and Decapentaplegic. Development 122: 3939-3948.

Thummel, C.S. and V. Pirrotta. 1992. N ew pCaSpeR P element vectors. Drosphila Inf. Serv. 71: 150.

Treisman, J.E. and G.M. Rubin. 1995. wingless inhibits morphogenetic furrow movement in the Drosophila eye disc. Development 121: 3519-3527.

Vandromme, M., C. Gauthier-Rouviere, N. Lamb, and A. Fernandez. 1996. Regulation of transcription factor localization: Fine-tuning of gene expression. Trends Biol. Sci. 21: 59-64.

Xu, T. and G.M. Rubin. 1993. Analysis of genetic mosaics in developing and adult Drosophila tissues. Development 117: 1223-1237. 


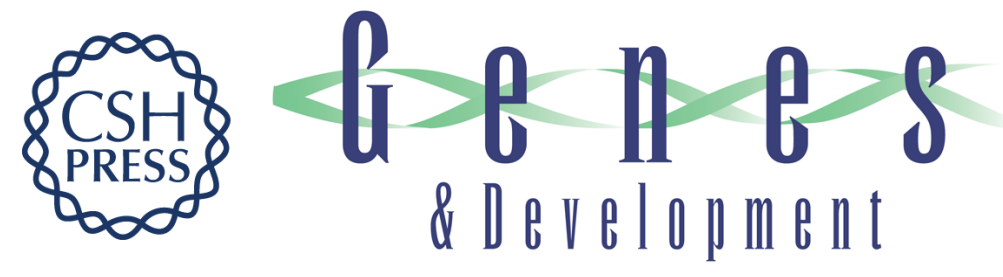

\section{The Homothorax homeoprotein activates the nuclear localization of another homeoprotein, Extradenticle, and suppresses eye development in Drosophila}

Chi-Yun Pai, Tung-Sheng Kuo, Thomas J. Jaw, et al.

Genes Dev. 1998, 12:

References This article cites 55 articles, 27 of which can be accessed free at: http://genesdev.cshlp.org/content/12/3/435.full.html\#ref-list-1

License

Email Alerting Receive free email alerts when new articles cite this article - sign up in the box at the top Service right corner of the article or click here.

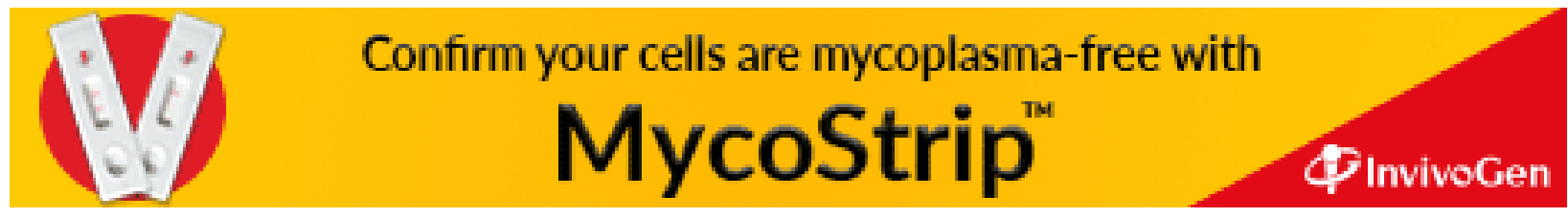

